\title{
CLAUDIO SÁNCHEZ-ALBORNOZ EN LA HISTORIOGRAFÍA SOBRE LA EDAD MEDIA HISPANA
}

\author{
Por \\ JOSÉ LUIS MARTÍN
}

\begin{abstract}
El 7 de abril de 1993 se cumplieron cien años del nacimiento de Claudio Sánchez-Albornoz y Menduiña que fue durante toda su vida un estudioso del pasado medieval preocupado por el presente de España; el primero le debe una gran parte de cuanto hoy sabemos gracias a sus enseñanzas y a las de los discípulos formados en las Universidades de Barcelona, Valladolid, Madrid, Burdeos, Mendoza, Rosario, La Plata y Buenos Aires. A la construcción del presente español colaboró como Diputado en Cortes, Ministro de Asuntos Exteriores, Embajador en Lisboa y entre 1962 y 1970 Jefe del Gobierno republicano en el exilio.

Historiador serio y político «aficionado» que se tomó en serio la política, historió medio en broma medio en serio su propia actividad política en numerosos artículos recogidos en Españoles ante la Historia, De mi anecdotario politico, Ensayos sobre Historia de España, Dipticos de Historia de España, Mi testamento histórico-político, Confidencias, Con un pie en el estribo, Aún... en los que pueden verse junto a anécdotas y reflexiones sobre la historia actual de España, las opiniones que a Don Claudio merecieron políticos españoles y europeos como Aldo Moro, Pietro Nenni o el general De Gaulle a los que trata como Jefe del Gobierno en el exilio, del que sólo regresa tras la muerte del general Franco.

El recibimiento, los homenajes, las distinciones y los premios que recibió don Claudio en su primera visita a España tras cuarenta años de exilio no fueron suficientes para convencerle de que fijara su residencia en España y fue precisa una grave enfermedad para que, según confesaba, se deja-
\end{abstract}

"CUADERNOS DE ESTUDIOS GALLEGOS", Tomo XLII, Fascículo 107, Santiago 1995. 
ra secuestrar por sus hijos con los que pasó en Ávila los últimos meses de su larga vida. La política le llevó a nacer en Madrid «el día antes o el día después de que su padre jurase el cargo de diputado a Cortes por Ávila», según su alumna Hilda Grassotti, y a su muerte fueron los políticos a Ávila para rendir el último homenaje, para reconocer los méritos políticos y profesionales de don Claudio. La España oficial se volcó, como lo había hecho en los últimos años y como lo haría después de muerto dando toda clase de facilidades para crear la Fundación Sánchez-Albornoz, y el Gobierno Civil de Ávila fue su última morada antes de ser enterrado, como era su deseo, en el claustro de la catedral abulense, con repique de campanas y anuncio de su muerte a los cuatro vientos, según recordó en el acto de investidura como Doctor Honoris Causa por la Universidad de Oviedo: «Hoy ya no se hacen esas cosas, pero yo os pido... que cuando llegue mi hora pidáis en Ávila que se recuerde la vieja práctica y que desde lo alto de la torre mocha de San Pedro, vecina de la casa de mi padre, que ya no existe, en la cual jugué, amé, sufrí y recé, el monaguillo grite: Por el alma de don Claudio Sánchez-Albornoz muerto en Argentina, adorando a España».

La paradoja y la polémica que le acompañaron en vida no le abandonaron en la tumba. Algunos católicos, olvidando sus continuas profesiones de $\mathrm{fe}$, lamentaron que un republicano tan notorio fuera enterrado en el claustro catedralicio. Sin duda, no habían leido su autodefinición como «católico, liberal, demócrata y republicano». Como católico fue enterrado en lugar sagrado, y como liberal y demócrata tuvo derecho a la presencia de representantes de todos los partidos democráticos españoles; su republicanismo no impidió que los reyes se interesaran por su salud ni que le fuera concedido el premio "Príncipe de Asturias»y, antes, las grandes cruces de Alfonso X el Sabio y la de Carlos III.

\section{CINCUENTA AÑOS DE ESTUDIOS HISTÓRICOS}

La gran obra de don Claudio se inicia en 1922 cuando Menéndez Pidal le «obliga» a presentarse al premio convocado por las Cortes para celebrar el duodécimo centenario de la batalla de Covadonga. Entre 1921 y 1922 Sánchez-Albornoz viaja incansable y trabaja en los archivos de León, Astorga, Oviedo, Gijón, Lugo, Santiago, Tuy, Madrid, Lisboa, Braga... hasta entregar a fines de 1922 su estudio sobre Instituciones sociales y politicas del reino de Asturias, dividido en cinco partes dedicadas respecti- 
vamente a la historia política de Asturias, a las instituciones de época visogoda, del reino astur, del reino leonés, y a la Iglesia, las letras y el arte de la época ovetense. Las Instituciones nunca fueron publicadas pues cada una de sus partes fue ampliada, matizada, dividida en numerosos artículos que irán apareciendo desde 1924 y permitirán, finalmente, que se publiquen tres tomos a partir de 1972 con el título de Orígenes de la nación española. Estudios críticos sobre la historia del reino de Asturias.

Entre 1922 y 1972 don Claudio forja una cadena de artículos y libros el primero de cuyos eslabones es su estudio sobre Las behetrías del que derivan dos grandes líneas de investigación: por un lado, la behetría se relaciona con la supervivencia de hombres libres en una época en la que Europa se distinguía por el predominio de los semilibres y siervos, y por otra parte, la institución de la behetría es una forma de encomendación, de la búsqueda de protección que se halla en la base del feudalismo. La existencia de hombres libres en los reinos occidentales de la Península es uno de los temas centrales de la obra de don Claudio, y de la existencia o no de estos hombres depende en gran medida la utilización de un sistema $\mathbf{u}$ otro de poblar las tierras ocupadas, aspectos que han sido analizados en sus trabajos sobre despoblación y repoblación del valle del Duero o sobre los pequeños propietarios libres. Estudia los orígenes del feudalismo en 1942 y a este trabajo han seguido otros muchos sobre el beneficio prefeudal, España y el feudalismo carolingio...

Aunque por su formación don Claudio sea ante todo historiador de las Instituciones, en numerosas ocasiones ha estudiado la vida económica en el reino asturleonés comenzando por los trabajos - 1928 - sobre la primitiva organización monetaria de León y Castilla, el precio de la vida, moneda de cambio y moneda de cuenta...; y en algunos casos ha superado el límite cronológico del reino asturleonés para hablar, por ejemplo, de inflación en León y Castilla hacia 1200 o de Alfonso el Sabio y la economía dirigida...

Las ciudades apenas tienen importancia durante el período estudiado por don Claudio, pero al tema dedicó una de sus más tempranas y mejores obras: Estampas de la vida en León hace mil años, publicada en 1926, en la que se reconstruye la vida en León: la ciudad y sus monumentos, la sociedad, la economía, la religión y la cultura, las instituciones, los precios, los sucesos, las pervivencias romanas y visigodas, la presencia judía, las influencias islámicas... en un lenguaje literario que convierte un libro de difícil lectura en una obra capaz de mantener la atención del lector no especializado.

Los estudios de Historia política son muy numerosos por lo que sólo

"CUADERNOS DE ESTUdiOS GALlEGOS", Tomo XLII, Fascículo 107, Santiago 1995 
cabe recordar algunas de sus obras relativas a los orígenes del reino de Pamplona, a las singularidades de Castilla, a las batallas de Guadalete y Covadonga... En su afán por comprender la Alta Edad Media, don Claudio remonta sus estudios hasta la época romana en la que estudia el municipio, el culto al emperador, la romanización, la tradición jurídica romana..., y pocos como él conocen el mundo visigodo del que estudió las asambleas políticas, el Senado...

Sin ser arabista, publicó Sánchez-Albornoz miles de páginas sobre la historia de la España musulmana, y desde los «Cuadernos de Historia de España» por él creados en Buenos Aires, favoreció la traducción y difusión de las obras de autores musulmanes; entre sus obras personales destacan la colección de textos reunidos bajo el título La España musulmana, y sus visiones de conjunto sobre el papel jugado por la España cristiana entre el Islam y Europa...

La elaboración científica de tantas y tan importantes obras no habría sido posible sin un análisis detallado de las fuentes utilizadas, tarea a la que dedica una parte considerable de todos y cada uno de sus artículos y monografías así como trabajos específicos sobre las crónicas musulmanas o sobre la historiografía cristiana de los siglos VIII al XIII; y no menos importantes son los estudios dedicados a la crítica y edición de diplomas medievales, que aparecen en todas sus obras.

La extraordinaria erudición de que hace gala Sánchez-Albornoz en todas sus obras dificulta en ocasiones la lectura; las notas al pie de página no se reducen a servir de apoyo al texto, están dotadas con frecuencia de vida propia y si por un lado garantizan o refuerzan las afirmaciones a las que aluden, por otro abren nuevas perspectivas, plantean problemas nuevos, resuelven viejos enigmas y siempre es necesario leerlas con atención para captar en toda su intensidad el pensamiento y las preocupaciones del autor. Los artículos de don Claudio son en muchas ocasiones el desarrollo de una posibilidad entrevista y expuesta en obras anteriores y dan lugar a nuevas ampliaciones e interrogantes que le obligan a volver sobre el tema, hasta aclarar y aclararnos totalmente sus dudas; en apariencia y vista de un modo superficial, la obra de Sánchez-Albornoz vuelve siempre sobre sí misma y se repite constantemente, pero una lectura atenta de toda su producción permite ver los progresos realizados y comprender las enormes dificultades que el historiador ha tenido que vencer para asentar cada una de sus afirmaciones y basar en ellas los pasos siguientes; ninguno de sus artículos es superfluo aunque en todos puedan hallarse coincidencias y puntos de vista expuestos en otras ocasiones.

"CUADERNOS DE ESTUdiOS GALLEGOS", Tomo XLII, Fascículo 107, Santiago 1995. 
Los historiadores españoles no sólo estamos en deuda con don Claudio por sus aportaciones personales sino que le debemos en muchos casos el haber podido investigar y publicar nuestros hallazgos; él fue quien entre 1918 y 1922 puso fin al cierre hermético de numerosos archivos; a él se debe la creación de dos de las más importantes revistas históricas españolas: el «Anuario de Historia del Derecho Español» y los «Cuadernos de Historia de España»; obra suya es también la creación en el Centro de Estudios Históricos de Madrid del Instituto de Estudios Medievales en 1932, y si las circunstancias le hubieran permitivo llevar a cabo sus proyectos no hay duda de que hoy dispondríamos de colecciones documentales comparables a los «Monumenta Germaniae Historica».

\section{MAESTRO INDISCUTIBLE Y DISCUTIDO}

Hablando del carácter polémico de sus escritos recuerda don Claudio que «si yo creyese en el destino - creía en él- pensaría que había nacido marcado por los hados para volver por la verdad que encierran las viejas teorías en pugna con los extremos insensatos de las nuevas; a tal punto he consagrado muchas de mis horas a rechazar no pocas tesis peregrinas alegremente aventadas por la malsana inclinación de los hombres de estos tiempos a asombrar a sus contemporáneos con las más extrañas novedades»).

Muchas han sido las «extrañas novedades» que don Claudino se ha visto obligado a refutar y muchas más las que, desdeñoso, ha pasado por alto porque creía, con el dicho popular, que el mejor desprecio es no hacer aprecio, que hablar de alguien es concederle importancia, reconocer su valía: «A cambio de mis críticas no he dejado, empero, de honrar a algunos estudiosos por mí enfrentados... Como dije un día... no toreo sino miuras y no armo caballeros sino a príncipes. Al discutir con quienes discuto reconozco su jerarquía científica. No hubiera tomado la pluma para contradecir a quien no creyese digno en enfrentamiento», escribe en el prólogo a Estudios Polémicos, obra en la que se recoge una mínima parte de las polémicas albornocianas, seleccionadas «por la variedad de temas y de autores contradichos y por su relativa brevedad», pues incluir todas las refutaciones habría exigido reeditar las obras completas de don Claudio.

Sánchez-Albornoz se considera y comporta como un caballero andante que no puede ni debe consentir críticas a la belleza o a la virtud de su dama: «no puedo guardar silencio cuando tropiezo con un error histórico 
y menos aún cuando ese error enfrenta una verdad por mí descubierta y defendida o que tenga por firme... He jugado mi vida a la carta de la honra y de la dignidad...». Caballero que confiesa no ser «versallesco y es notorio que no soy tampoco ni blando ni manco», don Claudio, en sus últimos años, teme que sus polémicas le hagan pasar a la posterioridad con fama de cascarrabias que nada encuentra bien, que disfruta atacando, incapaz de reconocer méritos ajenos... y nada más lejos de la realidad: «siempre he estado pronto a ayudar a cuantos se acercaban a mí, cualquiera que fuese su condición y cualquiera que fuese el esfuerzo que yo debiera hacer para complacer a quien me abordara científicamente...», hecho que confirman cuantos se acercaron a él, entre los que me cuento, pero que no invalida la acidez de sus críticas, lanzadas contra maestros como Menéndez Pidal o contra «jóvenes profesores»-ya no tanto- como Estepa, Mínguez o Valdeón pasando por compañeros de estudios o de docencia (Galo Sánchez, Ramos Loscertales, Floriano, Paulo Merea...), discípulos y alumnos de discípulos (García Gallo o Ubieto), maestros extranjeros consagrados (Brunner, Barrau-Dihigo, Mayer, Dahn, Dozy...), historiadores de épocas preteritas (Pérez Puyol, Gayangos, Saavedra...) sin olvidar a Fray Justo Pérez de Urbel, Álvaro d'Ors, María Rosa Lida, Lecoy o Marcelo Vigil y Abilio Barbero a los que don Claudio pide consideren su crítica «como el espaldarazo del viejo caballero andante en la investidura de armas de los noveles caballeros».

Aunque a veces haya tenido que enfrentarse profesionalmente a sus maestros y exponer teorías contrarias a las aprendidas en la Universidad o leídas en los libros de sus profesores, Sánchez-Albornoz es un alumno agradecido que recuerda con cariño a los buenos maestros y olvida, piadoso, a los malos. Por sus artículos históricos o de divulgación pasan maestros como Hinojosa, Mélida, Menéndez Pidal, Asín, Madariaga, Ortega..., de todos los cuales confiesa haber aprendido, de todos los cuales se reconoce discípulo aunque en sentido estricto no lo fuera. Agradecido, el medievalista especializado en la Historia de España no olvida que su obra fue posible gracias a las ayudas y estímulos americanos, y a la historia de América, de la América hispana, dedica también una parte de su producción.

$\mathrm{Al}$ respeto a los maestros sucede el respeto de los alumnos, directos e indirectos, que participan activamente en los homenajes ofrecidos a don Claudio con movito de cumplir los setenta años de vida y los casi cincuenta de docencia, al cumplir los noventa, con motivo de su muerte... Quienes asistieron a sus clases destacan la profundidad de su información, la nove- 
dad de los métodos empleados, la amenidad de sus explicaciones y el interés que creaba en los alumnos. Personalmente, tuve ocasión de oirle en un congreso celebrado en Niza en 1970 y puedo afirmar que su exposición, a pesar de la aridez del tema elegido y pese al gran número de documentos utilizados para la elaboración, fue una de las más amenas que he oído nunca.

\section{EL ENIGMA HISTÓRICO ESPAÑOL}

Un hombre que supo mantener a lo largo de toda su vida una actitud firme ante lo que él consideraba su deber de español no podía dejar sin respuesta los escritos de otros historiadores cuyas teorías no se limitaban a contradecir las de don Claudio sino su propia vida, su forma de ser. Pierre Vilar comprendió perfectamente esta simbiosis entre vida y obra de SánchezAlbornoz, entre lo que él consideraba debía ser la actitud vital del español y su actitud polémica, cuando afirma: «No os reconoceríamos, apreciado don Claudio, si fuerais más prudente o menos orgulloso de lo que conviene a un español» y don Claudio sabe bien qué conviene a un español pues ha dedicado miles de horas y millares de páginas a exponer sus ideas sobre el carácter español, a enfrentar en España un enigma histórico las ideas vertidas por Américo Castro sobre la realidad histórica de España.

Para Castro, España es el resultado de la acción de tres fuerzas representadas por los judíos, los musulmanes y los cristianos, y su nacimiento debería ser fechado, por consiguiente, en el año 711. En 1492 España habría adquirido las características peculiares que la diferencian y la aislan de Europa y que la conducirán al retraso y al fracaso: los españoles, dominados por las preocupaciones religiosas, no tienen aptitudes para la ciencia ni para la técnica y su carácter, fuertemente marcado por las corrientes judías e islámicas, permanecerá invariable a lo largo de la historia. Sánchez-Albornoz reacciona ante estas ideas por un triple motivo: como historiador al que interesa no sólo la mentalidad sino la vida en conjunto de los grupos humanos no puede aceptar unas conclusiones basadas principalmente en los textos literarios y en las que no se han tenido en cuenta las instituciones ni la economía; como medievalista que en sus trabajos ha defendido la importancia decisiva de la Reconquista en la formación del carácter español no puede aceptar su minimización frente a la influencia judaica y musulmana, y, por otra parte, concibiendo la historia como cambio, como marcha hacia la libertad y la racionalización no puede 
admitir que el carácter español se halle plenamente formado en 1492; aceptarlo sería aceptar un determinismo suicida que afecta no sólo a la historia medieval española sino que puede condicionar la historia actual y futura de España. Por estas razones, demasiado esquemáticamente expuestas, Sánchez-Albornoz se opone abiertamente a las teorías de Américo Castro al que combate en numerosos artículos que desembocan en España. Un enigma histórico y en los artículos reunidos en 1973 bajo el título El drama de la formación de España y los españoles. Otra nueva aventura polémica.

Si el carácter de un pueblo se forja en su historia, habrá que conocer ésta en toda su amplitud, y si este pueblo es el español será necesario explicar cómo se ha formado España, sin olvidar que, según sea el punto de vista del historiador, así serán sus conclusiones, motivo por el que don Claudio dedica un apartado a exponer sus ideas sobre El juego de fuerzas en la Historia. Sánchez-Albornoz está convencido de que durante la Prehistoria se ha ido creando en cada pueblo un estilo de vida, se han formado los rasgos fundamentales de un temperamento que «aunque a veces se prolongan por siglos, no son perdurables ni constantes y en modo alguno pueden tenerse por invariables e indelebles» pero que, en cualquier caso, influyen en los héroes - en su defecto, en las minorías rectoras- que junto con el azar y el estilo de vida «han ido haciendo la historia y rehaciéndola»s.

A partir de este planteamiento se entiende el esquema de la obra de don Claudio: tras el capítulo metodológico-explicativo, Sánchez-Albornoz analiza la influencia del medio geográfico en la formación de algunos de los rasgos del temperamento español para, en los capítulos siguientes, analizar a través de un detallado estudio histórico los rasgos temperamentales, el papel de los héroes - genios, para quienes la palabra héroes tenga connotaciones militares - como el arcipreste de Hita, el comportamiento de las minorías rectoras de la sociedad... para en los tres últimos de los dieciocho capítulos plantearse España como unidad histórica, el fracaso o cortocircuito de la Modernidad española y las diferencias entre España y Europa.

A lo largo de las cerca de mil quinientas páginas de España las referencias al carácter español son constantes; ya antes del 800 los hispanos, pasionales más que calculadores y razonadores, luchan por su libertad sin tener en cuenta la fuerza del enemigo sea éste Roma, el reino visigodo o el Islam; son sobrios, generosos y resistentes; se mueven más por la fe en un hombre que por defender una idea pero cuando aceptan ésta luchan apasio- 
nadamente por imponerla y en su exaltación no admiten la disidencia; no les importa perder la vida por sus jefes o por sus ideas pero rechazan el sacrificio constante; son leales y fieles, insolidarios poco inclinados a asociarse y orgullosos; poco amantes del trabajo continuo y menos aún de la técnica, de la elaboración de los productos que les ofrece la tierra..., virtudes-defectos, rasgos temperamentales en suma, que ya se hallan en Marcial el primer español auténtico según don Claudio.

Podríamos seguir con Sánchez-Albornoz la evolución-permanencia del estilo de vida, de la contextura vital, de las características temperamentales del español a través de los tiempos, pero ni el tiempo ni el espacio de que dispongo lo permiten y, por otra parte, espero que basten estas líneas generales de su pensamiento y la intención que le mueve a escribir: «brindar a los españoles una imagen de su ayer y, por tanto, una esperanza frente a su mañana» porque contra lo dicho por Américo Castro y sus seguidores, a los historiadores compete «no dudar de la capacidad de los españoles para hacer lo que hayan hecho y hagan los pueblos más inteligentes de la tierra. Y para, olvidados de nuestras supuestas frustraciones creacionales, aplicar todo el potencial humano que existe en nosotros a renovar la vida hispana». Dicho con frase castiza, el español ante su historia debe «sostenella y enmendalla». No otra cosa hizo Marcial, iniciador de una larga lista de españoles cuyo último representante ha sido por ahora don Claudio Sánchez-Albornoz y Menduiña, liberal y conservador anticomunista al mismo tiempo, católico y republicano; político al que Azaña acusa de cobarde por no regresar a España al estallar la guerra pero que, contrariando su temperamento hispano - capaz de las mayores heroicidades momentáneas e inútil para los esfuerzos continuados - tuvo el inmenso valor de permanecer en el exilio hasta la muerte de Franco; a un hombre político admirado por la izquierda mientras permaneció en Buenos Aires y del que se apropió la derecha al regresar a España; a un medievalista que ha sido reconocido como maestro por todos y ha tenido que polemizar con casi todos; a un hispano que se debate entre la permanencia del carácter español y su lenta transformación; a un castellano que pretende hablar de España, de todos los españoles, y concede especial atención a Castilla, cuyo papel histórico resumió en las Cortes de 1931: «enfrenté la injusta frase orteguiana: "Castilla hlizo a España y la deshizo" y acuñé esta otra, absolutamente exacta: "Castilla hizo a España y España deshizo a Castilla"». 


\section{EL POLÍTICO HISTORIADOR}

La referencia de don Claudio a su intervención en las Cortes de 1931 no es gratuita porque Sánchez-Albornoz no renuncia a su condición de historiador ni siquiera cuando actúa como portavoz del partido azañista, de Acción Republicana. Quizá como recuerdo de ésta y de otras intervenciones en las que se mezclan política e historia recuerda don Claudio la tendencia de los historiadores a intervenir en política y la de los políticos a rehacer o manipular la historia y en un artículo periodístico recogido en sus Ensayos sobre Historia de España ${ }^{1}$, llama la atención sobre la atracción mutua entre política e historia y sobre el fracaso que en la mayoría de las ocasiones acompaña a quienes se atreven a cambiar de campo: «Cuando el político en vez de leer y meditar sobre las enseñanzas del pasado, se deja arrastrar por el deseo de escribir de Historia, fracasa de ordinario... Va a la Historia con el espíritu lleno de apriorismos y... busca en (el pasado) la comprobación de sus teorías, de sus preferencias y de sus pasiones partidistas...» y no está más acertado el historiador que «baja al tendido del gran ruedo del mundo, en que asiste, como curioso espectador, al juego, trágico a veces, de la vida pública... Está habituado a torear sombras, que saben esperar, que no acometen, que dan plazo a la reflexión, que se dejan observar. De pronto, se halla frente al toro del problema político diario, que acude furioso a la muleta, que no da lugar al análisis... Y con frecuencia se deja embestir por la urgencia del minuto. Acostumbrado a la duda científica, al estudio despacioso, a la madura reflexión, al lento análisis de los fenómenos históricos, se encuentra embarazado para actuar en la vida pública, en la que a cada hora es forzoso elegir... Y cuando regresa, arrepentido, al trato más placentero con las sombras, se siente en ocasiones frente a ellas sacudido por los recuerdos de sus luchas con la fiera cornuda de la actualidad de sus instantes de político y cree ver, a veces, la imagen de hoy en el ayer».

Se explica así que «la mayor parte de las deformaciones de la Historia sean obra de hombres públicos metidos a historiadores» (a ellos se deberían las teorías equivocadas y errores que circulan sobre el feudalismo, las libertades municipales, la organización gremial, el régimen parlamentario, los fueros, la inquisición, la guerra de las comunidades, la expulsión de los

\footnotetext{
'Madrid 1973, págs. 142-148, titulado El historiador y el politico.
} 
judíos...); y si para muestra basta un botón, Alfonso X puede ser el prototipo de historiador metido a político que, como tal, «malogró la obra de su padre, Fernando III. Indeciso, lento en sus resoluciones, analítico, débil de voluntad, vanidoso, se dejó seducir por la aventura de sus pretenciones al Imperio, no supo evitar la guerra civil con su hijo Sancho, murió solo y abandonado de su pueblo» y fue en definitiva, uno más de los historiadores-políticos que «padecieron persecuciones y amarguras».

A pesar de estas experiencias, es posible el equilibrio y, aunque él no lo diga, un buen modelo de historiador metido a político y de político que emplea y se sirve de la historia es Sánchez-Albornoz que en el citado artículo nos da la fórmula: «El historiador que en lugar de encerrarse en su torre de marfil y de limitarse al trato, placentero pero engañoso, con las sombras, se aventura, medroso y precavido, por las sendas de la política, ganará en agudeza de visión, en exigencia humana y en riqueza de perspectivas. Al habituarse a conocer las cosas y los hombres de su época, se hallará mejor preparado para estudiar y para juzgar los hombres y las cosas de ayer. Y como la Historia no es, al cabo, sino una gran curva aérea, que a través del presente, instantáneo y pasajero, salta del remoto ayer hasta el mañana misterioso, el político aprenderá también en la lectura y estudio de la Historia... ¡Si los historiadores conocieran por dentro la vida política...; y si los hombres públicos meditaran sobre la Historia!.

Siguiendo su fórmula, don Claudio fue con provecho historiador y maestro de historiadores y al mismo tiempo un hombre público que representó a la provincia de Ávila como diputado en las tres legislaturas de la Segunda República Española, llegó a ser vicepresidente de las Cortes, ministro de Asuntos Exteriores en dos ocasiones, embajador de España en Lisboa y, finalmente, entre los años 1962 y 1970 Jefe del Gobierno Español en el exilio aunque es de justicia reconocer que ya en estos años estaba plenamente desengañado de la política y si aceptó el cargo fue para evitar que éste recayera en Dolores Ibarruri, la personificación del Marxismo contra el que tantas veces tronó don Claudio en sus trabajos históricos, iniciados mucho antes de dedicarse a la política y continuados cuando ésta había dejado de interesarle, aunque la política y los políticos lo acompañarían hasta la tumba en el atrio de la catedral de Ávila hasta la que acudieron todos los políticos del momento en homenaje a quien, entre otras muchas intervenciones, defendió los puntos de vista de Acción Republicana, el partido de Manuel Azaña, sobre el proyecto de Constitución de la Segunda República y sobre la Reforma Agraria e hizo gala en ambos casos 
de sus conocimientos sobre el pasado medieval de España y especialmente sobre los señoríos que pretendía abolir la Ley de Reforma Agraria de 1932.

Para explicar la presencia de Sánchez-Albornoz en las Cortes tenemos que remontarnos a la historia familiar de don Claudio que al presentarse para diputado republicano en 1931 heredó los votantes de su padre monárquico que justificaría así el cambio: «Ha llegado tu hora. No quisiste seguirme en mi camino. Vas a interrumpir y a continuar mi tradición. A interrumpirla, porque yo fui y soy monárquico. A continuarla, porque fui y soy liberal, y porque fío en que no olvidarás mi ejemplo de desinterés y de generosidad. Sirve con entusiasmo a la Libertad y a la República, pero ten siempre en cuenta que por cima de ambas está España», recomendación que asumió plenamente don Claudio y a la que dio forma parlamentaria el 22 de octubre de 1931 cuando al defender con los catalanes una enmienda al artículo 48 del Proyecto de Constitución para que se declarase «obligatorio el estudio del castellano en todos los establecimientos de Primera y Segunda enseñanza de España», comienza su intervención declarando que la enmienda no responde exactamente al pensamiento de los firmantes pero «todos hemos aceptado el texto de la misma, con la mira puesta en le porvenir de la República y de España; hemos cedido cada uno una parte de nuestras opiniones; hemos descendido de nuestras posiciones ideales, porque, Sres. Diputados, se trata de algo trascendental para la vida de España».

Si la herencia paterna le lleva a la política y sus coincidencias con Azaña al partido Acción Republicana, es portavoz de este partido en temas tan decisivos como el proyecto de Constitución o la Ley de Reforma Agraria gracias a su conocimiento de la Historia de España, del que da las primeras muestras con el artículo La potestad real y los señorios en Asturias, León y Castilla durante los siglos VIII y XIII publicado en 1914, a los 21 años. En los dos casos, don Claudio, que era todo menos humilde y modesto, comienza recordando el error que su partido comete al encomendar la defensa de sus planteamientos a quien es sólo «un estudioso del pasado de España y que, por lo tanto, me han de preocupar sobre todo aquellos problemas en los cuales la historia juega un papel decisivo» (Constitución) o «pienso traer al debate lo que pudiéramos llamar la experiencia de la historia agraria española. En lugar de emplear mis días en el estudio de la anécdota histórica de reyes y príncipes, de magnates y de cortesanas, de guerras y de asuntos de alcoba palatina, me he dedicado al estudio de la historia del pueblo español y de la agricultura española: vengo, por lo

"CUADERNOS DE ESTUdiOS GALLEGOS", Tomo XLII, Fascículo 107, Santiago 1995. 
tanto, con el deseo de aportar esta experiencia mía a este debate... porque el problema de la Reforma Agraria excede de los límites, del marco de las cuestiones temporales del momento, para entrar con derecho pleno en las perspectivas de la Historia y, por tanto, tal vez no sea inoportuno que se deje aquí también oir la voz de un modesto estudioso del pasado».

Con este bagaje y con estas pretensiones se presenta don Claudio a exponer la postura de su grupo, favorable a una Constitución socializante, pero respetuosa con la tradición jurídica del mundo..., autonomista, pero sin daño para la unidad nacional..., una Constitución que procura mantener el equilibrio entre la realidad y el ideal o, en boca de un historiador, que trata de mantener el equilibrio entre el pasado y el mañana, esas dos fuerzas eternamente en choque a través del tiempo y del espacio. Aunque no coincide en todo con los socialistas (si coincidiéramos... no nos encontraríamos en estos bancos, sino en aquellos) Acción Republicana aplaude la socialización reflejada en el texto constitucional y con Acción Republicana su portavoz, que hace una declaración expresa de fe en el socialismo: Personalmente, a mi me interesa, además, declarar que un historiador, que un profesor de Historia no puede adoptar otra postura; que quien ha visto en los documentos y en las crónicas las transformaciones que a cada paso se realizaban en la organización social y económica de los pueblos; quien ha visto transformarse al siervo en colono, al colono en solariego, al solariego en hombre libre; quien ha visto triunfar a las ciudades de los reyes; quien ha contemplado la evolución de la propiedad a través de los siglos; quien ha visto hundirse las formas politicas y de gobierno que parecian más firmes; quien, al cabo, está convencido de que la Humanidad no se ha detenido nunca en su camino hacia la libertad y hacia la igualdad entre los hombres, no podia menos de estar también convencido de que el porvenir próximo ha de ser del partido socialista, que el porvenir es vuestro... y nuestro, porque al cabo trabajais por el bienestar de la Humanidad.

El autonomismo de la Constitución permite una vez más dar rienda suelta a los conocimientos históricos del orador que convierte la tribuna parlamentaria en una aula de Historia de España, historia de la unidad y de la diversidad, que han de ser tenidas en cuenta para corregir los errores gravísimos cometidos desde la época de los Reyes Católicos: éstos se limitaron a unir sus coronas; no procuraron crear órganos de coordinación entre ellos. No habia entre los reinos peninsulares... otro lazo de unión que la realeza común, que una politica internacional trabada y que una unidad religiosa firmísima. Los Austrias encontraron ese sistema medie- 
val y lo respetaron... En cuanto a los Borbones... crearon un Estado a la francesa... en armonía con sus necesidades de poder absoluto y la falta de órganos de coordinación entre los distintos reinos fue la causa de la decadencia de España porque - don Claudio es catellanista ${ }^{2}$ - algunos reinos de los que formaban la Corona de España hurtaron sus fuerzas a la empresa común, y Castilla sola no podía resistir la carga ingente del imperio español y éste se vino al suelo, deshecho en mil pedazos, en los tristes dias del Hechizado.

A estos errores viene a poner fin la Constitución al reconocer que España ha sido siempre y es una y múltiple lo quieran o no tanto los que pretenden crear al Estado unitario o centralista como quienes niegan la unidad suprema de España. Unidad y Diversidad pueden ser rastreadas a través de la Historia y don Claudio no perderá la oportunidad de hacerlo en un discurso que más tarde fue definido por su jefe político, Manuel Azaña, como «Discreto, algo premioso, golpes de erudición histórica, castellanismo...». Tras la invasión musulmana, recuerda el medievalista, se rompió la unidad de la Iberia romana y visigoda, entonces surgió el hecho diferencial de Cataluña; entonces se acentuó el hecho diferencial de Vasconia, porque Vasconia ha sido siempre, como lo es hoy, el baluarte de la tradición española. Los que hoy se llaman vascos fueron, en otro tiempo, los españoles que se negaron a aceptar la Lengua y la cultura latinas, de la misma manera que hoy se niegan a aceptar los pensamien-

\footnotetext{
${ }^{2}$ Quien el año 19 había pronunciado en la Universidad de Valladolid una conferencia titulada Vindicación histórica de Castilla, pedirá a los parlamentarios que sean justos con Castilla, que no acusen de explotador al reino que sólo fue la víctima del imperio español: ¡Castilla explotadora, cuando al cabo ha sido la víctima propiciatoria de todos! Todos saben que Castilla era un emporio de riqueza al comenzar la Edad Moderna; todas las ciudades de Castilla estaban pobladas de telares...; gremios importantes, gremios riquisimos construian iglesias y capillas; ferias se celebraran en Medina del Campo...; eran famosos los Consulados de Castilla allende el mar.. Sin embargo, como Castilla tuvo que sostener sola la carga del Imperio español, aquellas manos quedaron un día sin trabajo, los talleres se fueron cerrando poco a poco, las ferias se interrumpieron, los Consulados cesaron allende el mar y aquellas manos, que habian trabajado la madera o la plata, se tendieron pidiendo una limosna o un empleo. El Sr. Ortega Gasset ha dicho, en ese admirable libro que se titula «España invertebrada», que Castilla hizo a España y que Castilla la deshizo. Yo le pediría que sustituyera esta frase por esta otra: "Castilla hizo a España y España deshizo a Castilla».

El texto de la conferencia vallisoletana ha sido publicado por la Universidad de Valladolid en 1974 en un librito titulado Mis tres primeros estudios históricos.
}

"CUADERNOS DE ESTUDIOS GALLEGOS", Tomo XLII, Fascículo 107, Santiago 1995 
tos y las formas politicas del pueblo español... Vasconia ha conservado una reliquia maravillosa, que los filólogos tienen que agradecerle; pero Vasconia, al cabo, no es más que una parte de esa España vieja que ha legado a España aquellos rasgos de inflexibilidad, aquellos rasgos de estatismo que han perdurado a través de los siglos en nuestro país, donde también Galicia presenta algunos rasgos diferenciales, aunque por encima de cualquier diferencia España está trabada por una múltiple unidad: unidad étnica, unidad geográfica, unidad cultural, unidad de temperamento, unidad de destinos, y tanto la unidad como la diversidad han de ser respetadas por la República que ha de ser especialmente sensible a las diferencias porque, según don Claudio, mientras la Monarquía, el absolutismo y el centralismo se han entendido a maravilla en la Historia, los regimenes republicanos, respetuosos con la libertad del individuo lo son también con la libertad de las agrupaciones de los ciudadanos, naturales o politicas $y$, por tanto, con las agrupaciones llamadas regiones, a las cuales vamos a conceder la autonomía, teniendo siempre presentes las enseñanzas de la Historia, los paralelismos que pueden establecerse entre el mundo antiguo-medieval y el del siglo XX.

El desequilibrio entre la vida económica del Imperio romano y la base estatal de la ciudad produjo en la Edad Media la catástrofe del Imperio y si el mundo europeo no acierta a encontrar una fórmula superestatal por encima de las naciones, que son la base de la organización del siglo XX, la civilización occidental volverá a caer en el caos de la Edad Media porque la organización en compartimentos estancos, en naciones, es más una traba que una ayuda a la economía continental que encuentra en las fronteras de esos compartimentos estancos erizados de barreras aduaneras gigantescas, los mayores obstáculos para su desarrollo.

La solución se encuentra en ajustar la organización política a la económica, en convertir a Europa en la unidad política que corresponde a una economía continental, y en este sentido trabaja la Historia, aunque por el momento el historiador metido a político no puede decir si el nuevo paso ¿podrá realizarse, se hará en unos decenios o serán necesarios otros mil años, como en la Edad Media, para que podamos formar el super-Estado continental?; en la creación de esta nueva unidad política debe trabajar España porque trabajar por Europa es realizar una política continuadora, al cabo, de la política de catolicidad de España en el siglo XVI; una politica de universalidad, que seria, al fin, una politica castellana y una politica española.

"CuAdernos De eStudios gallegOS", Tomo XLll, Fascículo 107, Santiago 1995. 
Meses después será llamado a defender e intentar mejorar el proyecto de Ley de Reforma Agraria y su intervención es un claro reflejo de sus conocimientos y también de su apasionamiento polémico manifestado en las obras históricas e igualmente en su labor política; con orgullo proclama don Claudio años más tarde: "Yo, en el curso de mi ya larga vida, no he sido - me atrevo a afirmarlo - sino un historiador. Un historiador que ha consagrado su existencia al estudio del ayer de España. El conocimiento de ese ayer y el amor a mi patria me lanzaron a la vida pública. El haber visto cambiar y mudarse todo en el mundo en el curso de los siglos, me hizo luchar otrora, y seguir luchando hoy, por la transformación ordenada de la España en que nací», palabras que explican su intervención en las Cortes y los dos artículos que, años después dedicará a la Reforma Agraria para resumir sus aportaciones al proyecto de 1932 y su oposición a los intentos de modificar la Ley de Reforma por parte de la Derecha en 1935, oposición que mereció la felicitación, no exenta de reproches, de un diputado socialista: - «Gran discurso, muy distinto del que le escuchamos sobre el mismo tema en las Constituyentes», a lo que responde don Claudio: «En ellas tenía yo el deber de conciencia de frenar a una Cámara con gran mayoría izquierdista, ahora he juzgado mi deber empujar a un parlamento dominado por las derechas» o, dicho de otra manera, el sitio de don Claudio fue siempre la oposición y la paradoja uno de sus lemas, paradoja que se observa con claridad en la definición que de sí mismo ofrece en repetidas ocasiones como «católico, liberal, demócrata y republicano», términos compatibles hoy pero irreconciliables en los años treinta.

La presencia de un medievalista en las Cortes que discuten el proyecto de Ley de Reforma Agraria se explica porque en varias de las bases se hace mención explícita de los señoríos y, por ejemplo, en la base $5^{\mathrm{a}}$, apartado $6^{\circ}$ se declaran susceptibles de expropiación para su posterior reparto entre los campesinos las tierras «que constituyeron señoríos jurisdiccionales y que se hayan transmitido hasta llegar a sus actuales dueños por herencia, legado o donación. También lo serán aquellas tierras de señorío que se hayan transmitido por el vendedor con la fórmula de a riesgo y ventura, o en las que se haya consignado por el cedente que no vendría obligado a la evicción o saneamiento conforme a derecho porque enajenaba su propiedad en las mismas condiciones en que la venía poseyendo»; en la base $8^{\mathrm{a}}$ se regula la forma de expropiación «cuando se trate de bienes de señorío jurisdiccional o de los comprendidos en la Base $5^{\text {a }}$, pertenecientes a la extinguida Grandeza de España»; en la base $9^{a}$ se dispone la ocupación inmediata de las fincas incluidas en el Inventario de bienes susceptibles de expropiación y el 
pago de unas cantidades a los propietarios hasta que se decida la expropiación y sus modalidades, y en la Base 22 se dispone: «quedan abolidas, sin derecho a indemnización, todas las prestaciones en metálico o en especie provenientes de derechos señoriales, aunque estén ratificadas por concordias, laudos o sentencias...» La complejidad del tema es tal que serán precisas numerosas normas aclaratorias y decretos como la Orden del 10 de marzo de 1933 y el Decreto del 24 de noviembre del mismo año para fijar las normas que determinen, «en cada caso, el carácter señorial de las prestaciones que quedan abolidas, a fin de que los que fueron pagadores puedan proveerse de un título declarativo de la inexistencia del gravamen, con el cual se lleve a cabo la cancelación de las inscripciones o menciones de dichos gravámenes en el Registro de la Propiedad» ${ }^{3}$.

Junto a normas administrativas que dejan en manos del Instituto de Reforma Agraria («contra sus acuerdos no se dará recurso alguno») la decisión sobre el carácter señorial de las prestaciones y fijan el procedimiento para incoar y dar curso al expediente, el Decreto, en sus artículos 2 a 4 , intenta definir las prestaciones señoriales:

Para determinar el carácter señorial de una prestación se atenderá exclusivamente al origen de la misma, sin que pueda considerarse en ningún caso convalidada por la prescripción, ni por transformaciones, de su carácter jurídico dimanantes de concordias, laudos o sentencias, ni por el título oneroso o gratuito mediante el que fueron adquiridas por el perceptor o sus causantes.

Se presumirá siempre que las prestaciones provienen de derechos señoriales:

1. Cuando así resulte del título de señorío o cuando hayan sido originariamente constituidas a favor de las personas que en la fecha de la constitución tuvieran jurisdicción sobre los territorios o pueblos en que recaigan, aunque hayan sido transformadas después o declaradas de carácter civil por concordias, laudos, sentencias, anteriores o posteriores a 6 de agosto de $1811^{4}$.

${ }^{3}$ El Decreto fue publicado en la Gaceta del 26 de noviembre de 1933.

${ }^{4} \mathrm{La}$ aclaración de que el origen de la prestación basta para anularla a pesar de posibles acuerdos entre las partes pretende, sin duda, evitar que se legitimen, como ha hecho en diversos casos el Tribunal Supremo, prestaciones señoriales abolidas en principio desde el 6 de agosto de 1811 y «reestablecidas» en fallos de 1864, 65, 68 y 82 en los que se decidió «que si con posterioridad a aquel Decreto las prestaciones por él abolidas habían sido

"CUADERNOS DE ESTUdIOS GALLEGOS", Tomo XLII, Fascículo 107, Santiago 1995. 
2. Cuando tenga su origen en contratos celebrados con posterioridad al 6 de agosto de 1811, entre los pagadores y los que por sí o por sus causantes hayan ejercido jurisdicción sobre los territorios o pueblos siempre que estos contratos traigan causa de pleito pendiente o ya fallado, entre aquéllos y éstos.

3. Cuando los pagadores sean pueblos y el reparto de la prestación se haga entre sus vecinos.

4. Cuando no recaigan sobre fincas específicamente determinadas.

Si interpretamos bien el sentir de los reformistas, se entiende que tienen carácter señorial los derechos económicos con origen en la autoridad ejercida por los beneficiarios en el momento de crearse la prestación o, dicho de otro modo, en el abuso de los señores que no conformes con percibir las rentas de sus tierras, exigen a quienes dependen de ellos pagos colectivos injustificados, que no recaen sobre fincas concretas y por tanto no pueden ser rentas o censos por la utilización de la tierra.

Con estas normas, se abre una puerta para resolver los litigios antiguos y los que pueden plantearse nuevamente, al margen de los tribunales ordinarios, y por ella entrarán numerosos municipios de toda España que, con razón o sin ella, se consideraban sometidos al pago de prestaciones y derechos señoriales e intentarán conseguir su abolición y el oportuno documento acreditativo. La iniciativa parte de los afectados pero, en ocasiones, son los Gobiernos Civiles los que impulsan y promueven las reclamaciones y exigen a los alcaldes que envíen relaciones de las fincas comunales, baldías y de señorío existentes en cada término municipal ${ }^{5}$.

objeto de transacción o contrato, subsistían con toda fuerza de obligar», según recuerda en 1936 el abogado de los beneficiarios de un censo en el pueblo segoviano de Madriguera en un pleito al que me he referido en el artículo publicado conjuntamente con Amanda Cabo, María Pía Senent y Dolores Moreno de Vega, La abolición de los derechos y prestaciones señoriales: la Ley de Reforma Agraria y su interés para la Historia Medieval y Moderna, «Espacio, Tiempo y Forma. Historia Medieval», V, 1992, págs. 303-316.

${ }^{5}$ Evidentemente, el malestar campesino y las protestas contra lo que consideran abusos señoriales es anterior a la proclamación de la República, pero ésta hizo concebir nuevas esperanzas especialmente desde el momento en que, a finales de junio de 1931, se llevó a cabo una encuesta nacional, provincia por provincia y municipio por municipio, para conocer las tierras comunales, baldías y de señorío susceptibles de mejoras o de distribución entre los colonos o entre los sin tierra. La aprobación de la Ley de Reforma Agraria es la respuesta de la Administración a los escritos de los Ayuntamientos y de los particulares,

"CUADERNOS DE ESTUdiOS GALlEGOS", Tomo Xlil, Fascículo 107, Santiago 1995. 
Aunque no en todos los puntos se hizo caso a don Claudio, éstas y otras disposiciones son reflejo en cierto modo de las aportaciones del medievalistaportavoz de Acción Republicana al que podemos atribuir el mérito de haber contribuido a la conservación de numerosos documentos medievales que serán presentados como prueba del carácter señorial de las tierras por los campesinos y concejos acogidos a la Ley de Reforma Agraria, conservados actualmente en los archivos del, hace unos días desaparecido, IRYDA que deberán ser consultados por los medievalistas, por los historiadores de la época moderna y por quienes se interesen por el Catastro del Marqués de la Ensenada presentado en muchos casos como prueba de la existencia o de la ausencia de señoríos y derechos señoriales ${ }^{6}$, sobre los que volveremos más tarde para recordar las reclamaciones presentadas en Galicia.

En el discurso pronunciado por don Claudio el 27 de agosto de 1931 recuerda que no es esta la primera vez que se lleva a cabo una reforma agraria y define la Historia de España como «una no interrumpida serie de reformas agrarias» cuyas enseñanzas llevan al historiador a recordar que de nada servirán los cambios políticos, el advenimiento de la República, si no se hace una reforma agraria que transforme la esencia misma de España, «que al aportar a las reservas humanas de España fuerzas que hasta ahora han permanecido alejadas de la vida de la cultura en esas aldeas miserables de toda la Península, que al dar un sustentáculo rural a la República y al traer al río de la vida hispana nuevas corrientes de sangre joven, no gastadas en la lucha de la civilización, se produzca lo que yo llamo la fecundidad de la República».

Tras analizar las líneas generales del proyecto y manifestar su acuerdo en líneas generales con manifestaciones sorprendentes hoy y más aún en 1932 en boca de quien se declara y es acusado de no ser socialista (Yo me atrevería... a afirmar... que al cabo de unos siglos la propiedad será un recuerdo histórico, como lo es ya la servidumbre y como lo son tantas viejas instituciones que existieron en tiempos, en los que parecieron eternas e inmutables, pero que han dejado de serlo por la fuerza de los hechos, por la fuerza de la razón humana), aprueba el mapa, la distribución geográfica de la Reforma Agraria, que se aplicará, según la base $2^{a}$ «en los términos municipales de Andalucía, Extremadura, Ciudad Real, Toledo, Albacete y Salamanca» respetando la línea que, con evidente exageración,

\footnotetext{
${ }^{6}$ Puede verse una primera aproximación al tema en el artículo citado en la nota 4.
} 
coincide según don Claudio «con el área de aplicación de los dos sistemas de colonización empleados en la repoblación de España: hombres libres, pequeña propiedad, al norte de esa raya; grandes latifundios, Ordenes militares, nobleza, al sur del Tajo, hasta el Mediterráneo». Los políticos actuales no han respetado esta línea divisoria y sólo en Extremadura y Andalucía existe el PER y se han dado intentos de poner en marcha la Reforma Agraria frustrada por la guerra de 1936-1939.

La reforma se aplica en estas provincias y se extiende a todo el territorio nacional cuando se trate de tierras «que constituyeron antiguos señoríos», medida que aplaude Sánchez-Albornoz porque, según afirma, «vivíamos en muchas aldeas de Castilla y del resto de España en plena Edad Media: no habían variado las cosas en mil años; era como una pesadilla la vida de esas aldeas, sometidas todavía a un señor; nada era en ellas de los aldeanos, ni sus propios hogares. Como hace mil años, el señor nombraba los jueces, los alcaldes, los alguaciles; llegadas las elecciones de Diputados a Cortes, el señor indicaba a quién debían votar sus colonos, y como el señor mandaba, el censo íntegro favorecía a aquel candidato que militaba en el mismo partido que el señor o que gozaba de sus simpatías», práctica a la que no fue ajena la familia de don Claudio que se transmite los electores y el escaño de padres a hijos sin que nada importe que uno sea monárquico y republicano el otro.

Bien está que se expropien y distribuyan las tierras señoriales que han permanecido en manos de los nobles, y justo es que se extienda la reforma a los bienes que fueron de nobles y están en las manos de gentes que no pertenecen a la nobleza porque la república debe estar más interesada en liberar a los colonos que en expropiar a los nobles y son muchos los pueblos «sometidos a un señor que no es nieto de los viejos señores, pero que sigue ejerciendo en realidad el poder, la potestad pública, en esas aldeas de señorío», realidad que la República no debe consentir como no debe ni puede tolerar, si de verdad quiere llevar a cabo una reforma digna de tal nombre, que se incluyan en la Reforma los grandes latifundios, sean o no señoriales, las tierras «que montan dos tercios, dos quintos o la mitad... del término de un pueblo y están todavía en manos de una sola familia» que, por el simple hecho de controlar la mayor parte de la tierra ejercen un poder real sobre los campesinos próximos, un poder no muy diferente del que tiene el señor.

El proyecto de Ley de Bases de la Reforma habla de los señoríos y todos opinan sobre ellos, «incluso los que nada sabían de la vieja historia medieval española, movidos por el legítimo derecho de defender sus intereses, o 
los de sus amigos, o los de sus partidarios», sin tener en cuenta la realidad histórica o tergiversándola para presentar los señoríos según su propio color: "Unos... les atribuyen magníficos servicios en la obra de la colonización de España; según estos amigos de los señoríos, los reyes entregaron a los señores las tierras para que las pusieran en cultivo; había necesidad de arar y de guerrear a un tiempo y los señores generosamente protegían a sus colonos, encargados de arar los campos españoles, mientras ellos defendían esa misma tierra contra el enemigo musulmán. Estampa histórica que no responde a la realidad... Para otros, el nombre de señoríos proyecta enseguida en su mente sombras entre las que empiezan a dibujarse viejos castillos almenados, horcas y mazmorras. Látigo en mano ven bajar a los señores de sus castillos almenados a ejercer en las aldeas supuestos derechos de pernada. Estampas históricas, falsas también como las otras»».

Frente a unos y otros, Sánchez-Albornoz presenta los señoríos en su contexto histórico, como un eslabón «de esa cadena de fenómenos e instituciones históricas que ha ido afirmando la libertad de los hombres en el transcurso de los siglos» por cuanto contribuye a transformar al siervo personal «que vivía como bestia en un establo, sin mujer, sin hijos, sin familia..., en el villano medieval que labra la tierra como colono, que puede crear una familia y que paga al señor como renta una parte de los frutos», y aunque toda definición es dificil, Sánchez-Albornoz se arriesga a definir el señorío, copio literalmente y comparto su definición, «como una unidad geográfica cerrada, dentro de la cual el Poder público ha hecho delegación de una parte de sus funciones en un señor. Este señor ejerce la potestad pública por delegación del rey, ejerce los poderes públicos por delegación del monarca y puede ser o puede no ser propietario de la tierra. El rey le ha dado su poder, lo único que el rey puede darle. Si además, él es propietario por otros caminos, unirá a su condición de señor la condición de propietario; si no, será tan solo señor. El labriego de esas tierras señoriales pagará en un caso impuestos; en el otro, impuestos y rentas... Al cabo de los siglos era difícil distinguir las prestaciones de carácter público - los impuestos - de las prestaciones de carácter privado - las rentas-que satisfacían los labriegos» y las Cortes de Cádiz intentarán separar la propiedad del señorío, recuperar la jurisdicción para la Nación y respetar la propiedad, política que se hará realidad en 1837 aunque con numerosos fraudes: señores que no habían sido nunca propietarios, que sólo habían tenido la potestad pública delegada del príncipe burlaron la ley y se hicieron reconocer derechos sobre las tierras de sus colonos, «tomaron de una manera inicua aquellas casas y aquellas propiedades que habían venido 
labrando hacía siglos los nietos de los primeros habitantes de aquellas tierras señoriales»; estos abusos han de ser corregidos por la República que ha de esforzarse por no caer en el error contrario, en apoderarse injustamente de las tierras de las que los nobles son propietarios: «la República no tiene otro remedio que indemnizarle si quiere obrar con justicia» y para obrar justamente deberá llevarse a cabo una investigación para conocer «los tipos de propiedad de cada propietario a expropiar, para saber por qué caminos adquirió sus heredades» pues puede ocurrir que al indemnizar a los propietarios se esté indemnizando a «los nietos del usurero, del logrero, que adquirió el señorío por trochas repugnantes» y se niegue toda contrapartida a los que prestaron a España en cualquier época un servicio que España no puede olvidar, a los que recibieron el señorío por servicios a España, a Castilla, a Aragón, a la Patria.

Don Claudio propone, en definitiva, que se expropien «sin indemnización aquellos señoríos en que se ha cometido un fraude histórico» y se pague una indemnización «como cualquier otra propiedad, los señoríos en los cuales el señor fue además propietario. No es tan difícil distinguir unos de otros», a pesar de lo cual ni el mejor especialista, don Claudio «quisiera empresa más ardua sobre mis pobres espaldas que la de decir en cada caso... éste fue sólo señorío jurisdiccional, este otro tuvo la propiedad y el señorío. Si la República quiere hacer una Reforma agraria justa, tiene que distinguir lo que la Historia ha distinguido».

También la experiencia histórica sirve a don Claudio para resolver el problema de los asentamientos y de los asentados, de los campesinos a los que se va a situar en las tierras expropiadas con o sin indemnización. Sánchez-Albornoz propone, en defensa de los campesinos, que no se les convierta en propietarios, que no se pague «con el dinero de todos los españoles (tierras que) puedan mañana ser absorbidas por la ventosa de los grandes propietarios, puedan volver, después, otra vez a redondear viejas y nuevas grandes propiedades»; si de él dependiera, don Claudio haría de estos campesinos no propietarios sino «lo que fueron los viejos colonos de realengo» que fueron la base de las libertades castellanas y, por lo que se refiere a la preferencia que establece la Ley entre jornaleros, pequeños propietarios y arrendatarios, don Claudio pide que primero se asiente a los que "vienen labrando la tierra» para que no se reproduzca la tragedia que supuso para muchos campesinos la desamortización de Mendizábal o la supresión de los viejos señoríos en 1811-1837, sin tener en cuenta el derecho histórico de los campesinos «que habían adquirido si no el dominio útil algo que se le parecía. Al cabo de los siglos, el señor no podía apartarles de 
sus tierras, el señor no podía aumentar las rentas que pechaban; ellos podían transmitirlas por herencia y podían disfrutarlas incluso estando ausentes de sus campos. Los siglos habían trabado un lazo jurídico entre el labriego y la tierra que explotaba desde siempre» y las sucesivas reformas agrarias (desamortización, supresión de señoríos) no tuvieron en cuenta este lazo, desarraigaron a los campesinos de los campos que venían cultivando tradicionalmente, los convirtieron en colonos temporales «a los que cada año podía expulsar el amo de sus campos, en colonos cuyas rentas podían ser aumentadas..., en colonos de cuyas casas... podían ser un día echados con derecho... Hoy no podemos repetir el error. Antes que nadie deben ser asentados esos labriegos arrendatarios de tierras que vienen trabajando, a veces cientos de años. Es, además, lo más barato para la República. Ellos tienen aperos de labranza, ellos tienen ganados, ellos tienen costumbre de labrar la tierra. Démosla; primero, ellos, y depués, todos los demás»..., con lo que don Claudio se oponía frontalmente a los planteamientos socialistas que daban preferencia a los jornaleros y pretendían, según don Claudio, convertirlos en colonos sin verdaderos derechos sobre la tierra con lo que mataban cualquier posible iniciativa de mejora por parte de los campesinos.

Otros dos problemas preocupan a don Claudio ante la reforma agraria: la recuperación de los bienes comunales, usurpados a lo largo de los siglos, en los pueblos de Castilla que también tienen derecho a «las caricias de la República» como lo tienen andaluces y extremeños que se beneficiarán de la reforma de manera directa; $\mathrm{y}$, para quienes nos pasamos la vida discutiendo si las rentas del señor medieval son señoriales o territoriales, no estará de más recordar con Sánchez-Albornoz que la concesión de tierras de poco sirve si no se facilitan los medios para ponerlas en cultivo: durante la Dictadura - conviene corregir a don Claudio y recordar que el proceso se inicia antes, en 1907, con la creación de la Junta Central de Colonización y Repoblación Interior - se compraron tierras y fueron distribuidas entre los campesinos que sólo tenían que pagar el 20 por 100 de su valor pues Acción Social Agraria adelantaba el 80 por 100 restante. A pesar de las ventajosas condiciones, no tan ventajosas pues con frecuencia se hinchó artificialmente el precio para favorecer a los propietarios, los campesinos no disponían del veinte por ciento y tuvieron que endeudarse con bancos o con usureros y tras el júbilo de la compra de la libertad se encuentran endeudados, peor que cuando dependian de un señor $o$, dicho con palabras de Sánchez-Albornoz: «La Acción Social Agraria dio el 80 por 100; los campesinos acudieron a un Banco o a un usurero, en busca del 
20 por 100 restante, y se terminó el contrato. Se celebró pomposamente el hecho, se dijo una misa, se pronunciaron unos discursos, se hicieron unas fotos, subieron al aire unos cohetes expresando el anhelo y la esperanza de los colonos; pero de la misa forma que las varas de los cohetes cayeron al suelo poco después, cayeron también enseguida al suelo las esperanzas de los campesinos... que tenían anualmente que satisfacer una renta muy superior a la que habían venido pagando hasta entonces. Las letras, los descuentos, los intereses... les seguía convirtiendo en esclavos, puesto que por él habían sustituido con desventaja al antiguo señor por el nuevo amo que nombraba también los Ayuntamientos, que nombraba los jueces e imponía o trataba de imponer en estos últimos tiempos incluso el Diputado constituyente».

Don Claudio es consciente de que los propietarios no aceptarán fácilmente que se les despoje de la tierra y que, con el dinero de todos, se ayude a los campesinos a pagar su deuda pero recuerda a los descontentos que si en Rusia se hubiera hecho la reforma agraria no imperaría allí el régimen comunista y si los dueños de la tierra «no tienen el espíritu de sacrificio bastante para asistir alegres a esta reforma... que asistan resignados, al saber que ella ha de impedir, a lo menos, que sufran en su carne y en sus bienes daños muy superiores a los que ésta va a producir en sus riquezas...». Se alineará al lado de los campesinos y siguiendo el ejemplo de los predicadores medievales pedirá a los propietarios que entiendan su postura y la de los partidarios de la Reforma a través de un ejemplo claramente medieval: «Los halcones de un señor castellano empezaron a comerse las gallinas de un labrador que cultivaba unas tierras no lejos del castillo señorial. Humildemente se quejó al magnate vecino. No escuchó éste sus demandas. El labriego hizo intervenir a un sacerdote. Los halcones siguieron despoblando el gallinero del campesino. Se hartó éste y mató a un halcón. El señor envió entonces a su gente e hizo crucificar al labrador para pasto de sus aves de presa. ¿Con quién os sentís solidarios? —apostrofé a la mayoría. Y la mayoría estuvo a punto de aplaudirme, según me confesó don Santiago Alba, presidente de las Cortes» en 1935, pero la mayoría no hizo caso a las enmiendas del medievalista siguiendo en este punto el ejemplo de los socialistas en 1932, actitud que lleva a Sánchez-Albornoz a lamentarse de «que la disciplina de partido nos obligue, a veces, a someternos al acuerdo mayoritario que juzgamos erróneo, torpe, y hasta a veces, disparatado». Para escapar a tales compromisos busqué en su día una honorable salida, que no fue otra que la embajada de España en Lisboa, aspecto que supera con mucho mi propósito de llamar la atención sobre las 
aportaciones del maestro de medievalistas Claudio Sánchez-Albornoz a la redacción del Proyecto de Ley de Bases para la Reforma Agraria y de las normas y reglamentos que completaron la mencionada Ley cuyo fracaso «significó el fracaso de la República».

No quisiera, sin embargo, terminar esta exposición sin, al menos, una breve referencia a temas hoy de actualidad, a los estudios sobre el apóstol Santiago que se reeditarán en fecha próxima, y, como he señalado antes a las reclamaciones contra los señoríos y las prestaciones señoriales presentadas por los campesinos gallegos. Sobre el primer aspecto, me remito al prólogo escrito para la reedición citada, y por lo que se refiere al segundo, reproduzco el catálogo-inventario, todavía inédito, preparado para el día en que se publiquen el catálogo de los fondos procedentes del Instituto de Reforma Agraria.

Los Registradores de la Propiedad enviaron al Instituto en su día una relación de las fincas susceptibles de ser expropiadas, de las que hay en el IRYDA un inventario; a él hay que añadir para Galicia una relación (4 de mayo de 1933) de fincas no declaradas en Santa Marta de Ortigueira (La Coruña) conservada en la Caja 1 de largo y explícito título: Datos complementarios aportados por los Registradores de la Propiedad sobre los bienes de la ex-grandeza de España, no declarados en su momento y, en consecuencia, no incluidos en el Registro de Bienes Expropiables.

En la caja 26 (Comunales y señorios. Varias provincias) se conservan para Lugo los siguientes documentos:

- Becerreá. Se pide la abolición de prestación señorial. 13 expedientes fechados entre el 7 y el 12 de julio de 1936.

- Cervantes. Solicitud de supresión de una prestación señorial. 8 de julio de 1936.

- Los Nogales. Se solicita la abolición de un censo de origen señorial. Hay ocho expedientes distintos, fechados entre el 5 de junio y el 13 de julio de 1936.

\section{Coruña. Caja 52}

Relación de bienes comunales de diversos municipios.

- Ares. (Redes, Ayto. de ---). D. Cesáreo Rojas y otros solicitan abolición de gravamen señorial sobre el fruto de diversas fincas de la parroquia de Caamouco. 28 de diciembre de 1934. Se acompaña documentación histórica.

- Arteijo. Información sobre despojos o alteraciones sufridas por los bienes públicos. 16 de junio de 1931 .

"CUADERNOS DE ESTUDIOS GALLEGOS", Tomo XLII, Fascículo 107, Santiago 1995. 
- Bergondo. (Vijoy, Ayto. de ---). Emilia Santiso de González solicita abolición de una pensión foral. 1 de julio de 1935.

- Boiro. La sociedad agraria y de oficios La Fraternidad pide la concesión a sus socios de tierras para labrarlas. 4 de septiembre de 1931.

- Boñar. La Junta Administrativa solicita la devolución al municipio de un terreno del que fue desposeido por desplazamiento del seto vivo. 28 de junio de 1931.

- Brión. (Guitiande, Ayto. de ---). Elena Tobio Campos solicita la abolición de un foro por ser de origen señorial. 6 de junio de 1935. Se incluye la carta foral, de 1519, original y transcripción.

- Conjo. Manuel Raices solicita abolición de foro llamado «Foral de la Fuente». 22 de febrero de 1936.

- Id. José Pereira solicita abolición del foro llamado Cancela Vella. 22 de febrero de 1936.

- Id. Petición realizada por María Seoane Tarrio para que se suprima el foro de Los Lorenzos. 22 de febrero de 1936.

- Corujo. Peregrín Pérez, presidente de la Sociedad de Agricultores solicita la derogación de las cargas que recaen sobre los foros. 26 de diciembre de 1934.

- Coruña. La Junta provincial Agraria remite acuerdo junto con dos instancias de Boiro y Puentedeume sobre abolición de prestaciones. 26 de marzo de 1934. (Sólo se conserva la nota del Servicio).

- Lousame. Instancia solicitando sean declarados de origen señorial varios foros. 26 de septiembre de 1934.

— Noya-Orro. D. Manuel Pérez López solicita abolición de prestación señorial que paga a la Sociedad Hijos de Simeón García. 11 de enero de 1935. Con referencias históricas a partir de 1168 fecha de la concesión de fuero a Noya por Fernando II.

- Outes. (Vilariño, Ayto. de ---). Juana Priegue Vázquez solicita abolición de prestación señorial. 7 de diciembre de 1935.

--Id. (Mosteiro, Ayto. de ---). Los vecinos solicitan la abolición de una prestación señorial. 30 de enero de 1936.

-Puebla de Caramiñal. Instancia de José María Míguez pidiendo la redención de un foro. 13 de enero de 1934.

- Id. Pilar Tubio Blanco solicita abolición de foro por ser de origen señorial. 28 de septiembre de 1935.

- Puentedeume. Exhorto del Presidente del Tribunal de Foros de Puentedeume pidiendo certificación sobre «si el conde Andrade ejerció jurisdicción y señoría en la villa de Puentedeume y en la de Ares. Si Enrique II 
otorgó al conde Fernand Pérez de Andrade el privilegio de jurisdicción...». 17 de diciembre de 1935.

- San Vicente de Vigo. Consulta hecha por Ramón Ares Grela sobre redención de foros. 23 de julio de 1934.

- Villarmayor. (Doroña, Ayto. de ---). Jesús Carabana Riveiros solicita la abolición de una prestación señorial que recae sobre foros. 24 de octubre de 1935.

\section{Lugo. Cajas 78-80}

\section{Caja 78. Señoríos y Comunales}

Copia de diversas escrituras:

— del Catastro del Marqués de la Ensenada, de 1753, del lugar de San Juan de Arrojos, hecha por el Archivero de Hacienda de Lugo.

- Inventario judicial de rentas forales de la casa de Villachambre, formado en 1781 al fallecer Manuel José Valcárcel.

- de venta de los bienes de Villachambre, ayuntamiento de Neira de Jusá. 5 de agosto de 1910.

— de división de bienes comunales, otorgada por Augusto Díaz y Juan Pérez. 17 de febrero de 1915.

Relación de bienes comunales.

- Abadín. Los vecinos comunican que el ayuntamiento desobedece la orden del Gobernador de permitirles el disfrute de los montes Valiño y Forcón. 20 de junio de 1931.

- Guimeray de Neira de Jusa. Ricardo Vázquez solicita abolición de prestación señorial. 9 de octubre de 1934.

- Guntín. Se solicita la anulación de una prestación señorial. 7 de marzo de 1935.

- Id. José López Mesa y otros vecinos piden se suprima una prestación señorial. 7 de marzo de 1935.

- Id. Labaste. Manuel Rodríguez solicita la supresión de una renta señorial. 30 de abril de 1935.

- Mondoñedo. (Argomoso, Ayto. de ---). Labradores del lugar denuncian al juez de Mondoñedo que intervino en el litigio por un monte comunal. 8 de mayo de 1931 .

- Monforte de Lemos. (Villamarín, Ayto. de ---). Los vecinos protestan por el despojo de un monte comunal. 27 de junio de 1931.

- Neira de Jusa. Ermitas Belón Simón y su marido solicitan sea abolida la renta feudal que pagan a Odón Moreno. 24 de agosto de 1934.

"CUADERNOS DE ESTUDIOS GALLEGOS", Tomo XLII, Fascículo 107, Santiago 1995. 
- Id. José García López solicita la abolición de una renta por considerarla de origen señorial. 4 de octubre de 1934.

- Id. Jesús Pereira solicita la supresión de rentas de origen señorial. 7 de noviembre de 1934.

- Id. Balbino Torneiro solicita abolición de prestación señorial. 29 de noviembre de 1934.

- Id. Dositeo Paraguá pide la redención del foro que pagaba a Ramón García Valiño. 5 de enero de 1935.

- Id. Ricardo Núñez solicita supresión de prestación señorial. 16 de abril de 1936.

- Id. Manuela Rodríguez pide se suprima una prestación señorial. 23 de abril de 1936.

- Id. José Rubianes solicita se suprima una prestación que cree de origen señorial. 25 de abril de 1936.

- Id. Bautista Vilela solicita la abolición de prestaciones señoriales. 25 de abril de 1936.

- Id. Francisco Telo Pérez pide se suprima una prestación señorial. 4 de mayo de 1936.

- Id. José María Álvarez pide la supresión de una prestación de origen señorial. 16 de mayo de 1936.

- Id. Manuela López solicita abolición de prestación señorial. 25 de mayo de 1936.

- Id. Máximo Díaz solicita abolición de prestación señorial. 15 de junio de 1936.

- Id. José Antonio Dacal solicita abolición de prestación señorial. 22 de junio de 1936.

- Santa Columba de Orrea. Antonio Enríquez denuncia la apropiación de unos terrenos de su propiedad. 20 de julio de 1932.

- Villalba. Denuncia contra vecinos que han intentado legitimar la propiedad de parcelas en los montes mediante informaciones falsas. 26 de julio de 1931.

- Villarpandín (Navia de Suarna). Varias personas solicitan sea declarada de origen señorial la renta que pagan a José María López Rellén, vecino de Coea, por recaer sobre fincas indeterminadas. 22 de julio de 1935.

\section{Caja 79}

- Antas de Ulla. Relación de montes entregados a la libre disposición del ayuntamiento.

"CUADERNOS DE ESTUDIOS GALLEGOS", Tomo XLII, Fascículo 107, Santiago 1995. 
- Id. Genoveva y Manuela Gómez solicitan abolición de prestaciones. 23 de abril de 1935.

- Balboa. Se pide información para lograr se suprima un censo considerado de origen señorial. 28 de septiembre de 1934.

- Becerreá. Manuel Fernández solicita sea suprimida una prestación por considerarla de origen señorial. 14 de agosto de 1934.

-- Id. Pilar López pide se suprima, por considerarla de origen señorial, la renta que paga a María González Fariña. 27 de agosto de 1934.

- Id. Ángel Arrojo solicita desaparezca la renta foral que paga a Gerardo Pardo. 10 de septiembre de 1934.

- Id. Teresa López pide la supresión de prestación señorial. 11 de diciembre de 1934.

- Id. Dionisio Simón se suprima una prestación de origen señorial. 4 de febrero de 1935.

- Id. Ramira Pereira pide la supresión de una renta señorial. 19 de junio de 1936.

- Id. Jesús Arias solicita se suprima una prestación señorial. 27 de mayo de 1936.

- Id. Carmen Rodríguez... 27 de mayo de 1936.

— Id. Antonio Souto... 27 de mayo de 1936.

— Id. José Carballo solicita... 28 de mayo de 1936.

- Cervantes. Varios vecinos preguntan la forma de reclamar la abolición de prestaciones señoriales. 28 de noviembre de 1935.

- Id. Emilio García solicita la abolición de una renta de origen señorial. 8 de junio de 1936 .

- Id. Jesús García solicita la abolición de una renta señorial. 8 de junio de 1936.

- Cormes. Se solicita la supresión de una pretendida prestación señorial. 3 de octubre de 1934.

— Id. id. 3 de octubre de 1934.

— Id. id. 7 de octubre de 1934.

- Doncos. Manuela Pérez solicita la abolición de una prestación de origen señorial. 13 de junio de 1936.

- Fonsagrada. Antonio Sampayo y otros piden la abolición de prestaciones señoriales. 20 de marzo de 1935.

- Jucio. Carmen López solicita se suprima una renta que considera de origen señorial. 18 de mayo de 1936.

- Láncara. Ricardo Álvarez solicita abolición de prestaciones señoriales. 3 de abril de 1935 .

"CUADERNOS DE ESTUdIOS GALLEGOS", Tomo XLII, Fascículo 107, Santiago 1995. 
- Lebaste. Manuel Rodríguez solicita la supresión de renta de origen señorial. 30 de abril de 1935 .

- Mondoñedo. Los vecinos piden se declaren de origen señorial y se supriman las prestaciones pagadas al extinguido coto señorial de Cima de Vila. 2 de agosto de 1934. Los orígenes se remontan al 14 de abril de 1666.

- Monterredondo-Sabiñao. Jesús López Vilariño solicita la supresión de la renta que viene pagando a los condes de Taboada. 3 de diciembre de 1934.

- Nogales (Los). Eliseo Santín solicita la supresión de un foro. 26 de abril de 1935 .

- Id. Bernardino Fernández solicita la abolición de un censo de origen señorial. 8 de junio de 1936 .

- Id. Román García solicita la anulación de una renta que considera feudal. 8 de junio de 1936.

- Id. Antonio Fernández pide la abolición de un censo de origen señorial. 16 de junio de 1936 .

— Id. Antonio Fernández... 16 de junio de 1936.

— Id. José García... 16 de junio de 1936.

- Id. Manuel Alba solicita la anulación de una renta foral. 26 de junio de 1936.

— Id. Manuel Rubio... 29 de junio de 1936.

— Id. Julia Pardo... 29 de junio de 1936.

- Piedrafita de Cebreros. Manuel Fernández solicita se suprima una prestación señorial. 4 de octubre de 1934.

- Id. Varios vecinos piden la supresión de rentas forales que consideran de origen señorial. 23 de noviembre de 1934.

- Id. Domingo Cela solicita se suprima la pensión señorial que satisface a Emilio Núñez. 24 de noviembre de 1934.

- Id. Manuel López pide se suprima una renta foral de señorío. 8 de mayo de 1935.

- Id. Manuel Fernández solicita la supresión de una renta foral por ser de señorío. 8 de mayo de 1935.

- Sarria. Manuel López solicita la abolición de una renta foral. 29 de abril de 1935 .

- Id. Faustino Rodríguez solicita la supresión de una prestación señorial. 13 de junio de 1935.

- Taboada. Manuel Moreiras solicita abolición de prestaciones señoriales. 19 de junio de 1935 .

"CUADERNOS DE ESTUDIOS GALLEGOS", Tomo XLII, Fascículo 107, Santiago 1995. 


\section{Caja 80}

\section{Comunales y Señoríos}

Relación de bienes comunales, municipio por municipio.

- Becerreá. Los vecinos piden información sobre la posible supresión de rentas forales. 2 de enero de 1936.

- Id. Jesús Arias solicita la supresión de prestaciones que considera señoriales. 7 de abril de 1936. (Se incluyen documentos originales de 1812).

- Id. Pedro Pérez solicita la supresión de una renta que considera de origen señorial. 18 de mayo de 1936.

- Id. Ricardo Neira solicita abolición de prestación que cree de origen señorial. 21 de mayo de 1936.

— Id. Dositeo Fernández solicita la supresión de una prestación señorial. 27 de mayo de 1936.

- Cangas de Foz. José y Francisco Cao solicitan se declare de origen señorial la prestación que pagan a Beatriz Rebellón. 24 de mayo de 1934. Se incluye el Catastro del Marqués de la Ensenada y documentos originales, con la transcripción correspondiente, desde 1632.

- Castillo de los Infantes. Los vecinos solicitan la supresión de prestaciones señoriales. 17 de junio de 1935.

- Chantada. José Antonio Vázquez pide sea declarada de origen señorial una prestación. 14 de julio de 1934.

- Cormes. Instancia solicitando la supresión de prestaciones señoriales. 7 de octubre de 1934 .

- Láncara. Los vecinos piden la abolición de supuestas prestacioṇes señoriales. 2 de octubre de 1934.

- Lebaste. Manuel Rodríguez solicita se suprima una prestación de origen señorial. 20 de agosto de 1939 (la primera solicitud fue de julio de 1936).

- Lugo (parroquia de San Juan de Pena). Pilar Gómez pide se suprima una renta foral. 30 de abril de 1931.

- Taboada. José Gacio da Viña solicita la abolición de una prestación de origen señorial 15 de noviembre de 1934.

- Triacastela. Pedro López protesta al pedírsele el pago de una renta foral que nunca pagó. 13 de noviembre de 1935.

— Id. id. 13 de noviembre de 1935.

-- Villaodrid. Antonio Ferández solicita la abolición de prestaciones señoriales. 8 de abril de 1936. 


\section{Orense. Caja 89}

\section{Comunales y Señorios}

Relación de bienes comunales de diversos municipios.

- Calvos de Randín. Vecinos de Randín denuncian la utilización por un particular de un monte comunal. 15 de agosto de 1932.

- Carballeda de Valdeorras. Los vecinos solicitan la supresión de una gravamen señorial. Se les devuelve el escrito por no estar redactado conforme a las normas. 16 de febrero de 1935.

- Celanova. El Ayuntamiento denuncia la cesión hecha a un particular, en 1921, de un camino público. 6 de julio de 1931.

- Id. Vecinos de Canabelas, Candarela y Vilanova piden la supresión de un foro que consideran de origen señorial. 27 de febrero de 1934. (Hay referencias a documentos de 1640 presentados como prueba).

- Cejo, Ledine Angüela y Condesende. Recibo de un Registrador d ela Propiedad conforme ha recibido los documentos concernientes a la abolición del foro denominado San Adrián de los pueblos de ---. 25 de noviembre de 1940.

\section{Pontevedra. Cajas 93-96}

\section{Caja 93}

- Lavadores. La Federación Provincial Agraria pide la supresión de foros creados el 4 de enero de 1796. 3 de febrero de 1936.

- Id. La Federación pide se supriman prestaciones que considera señoriales, que se remontan a los tiempos del conde de Colbe, «señor que fue de fueros y jurisdicción en esta comarca». 10 de febrero de 1936.

- Id. La Federación Provincial Agraria pide la abolición de prestaciones señoriales llamadas foros a las Monjas de Redondela. 12 de marzo de 1936.

- Id. Vecinos del lugar solicitan la supresión de foros señoriales cuyos orígenes hacen ascender hasta 1700.17 de marzo de 1936.

- Id. La Federación pide se supriman foros señoriales que considera creados por la casa Montenegro y Reboreda. 2 de abril de 1936.

- Meis. José Giráldez, vecino de la parroquia de Paradela pide la supresión del foro de la Capellanía de San Benito Frad. 20 de diciembre de 1935 (Aporta como prueba una escritura de 1803).

- Salvatierra de Miño. Vecinos de Fiolledo, Oleiros y Salvatierra solicitan abolición de foros que consideran de carácter señorial y cuyos orígenes remontan a las guerras carlistas. 12 de junio de 1935. 
— Id. Vecinos de Oleiros piden se suprima la renta foral de «Cabrón» que pagan a los herederos de Francisco Santos Domínguez. 5 de agosto de 1935.

- Id. Vecinos de Corzanes solicitan la supresión de supuestas prestaciones señoriales cuyos orígenes se remontan a 1662.15 de agosto de 1935.

- Id. Vecinos de Corzanes, Fiolledo y Oleiros solicitan la supresión de prestaciones que consideran señoriales. 15 de agosto de 1935.

(Se conserva un paquete con cuentas de los censos pagados, escrituras de foros, testamentos..., sin duda, aportados como prueba por las partes).

\section{Comunales y Señoríos}

Relación de los bienes comunales de diversos municipios.

- Lavadores. La Federación Provincial Agraria pide la supresión de las rentas señoriales que percibe la ex-duquesa de Valladares. 5 de octubre de 1935. (La parte reclamada presenta numerosos documentos, que se remontan a 1676).

- Nigrán. Benito Nandín, vecino de la parroquia de Camos, pide la supresión de la renta señorial que percibe o intenta percibir la ex-marquesa de Valladares. 20 de septiembre de 1935. (Entre otras pruebas, aporta una escritura de subforo, de 1790).

- Redondela. Vecinos de Tramaño, barrio de Cabanas, denuncian la ocupación de bienes comunales por un vecino. 30 de junio de 1931.

- Id. Vecinos de los barrios de Saramagoso y Sotojusto de la parroquia del Viso denuncian la ocupación violenta de bienes comunales. $10 \mathrm{de}$ julio de 1931.

- Rosal (El). El Alcalde informa de la desaparición de diversos bienes comunales. 24 de junio de 1931.

- Salvatierra de Miño. Vecinos de Fioledo, Oleiros y Salvatierra piden la abolición de foros que creen señoriales. 12 de junio de 1935 .

- Id. Vecinos de Oleiros solicitan la abolición de foros que consideran señoriales. 5 de agosto de 1935.

- Id. Vecinos de Fiolledo piden la supresión de los foros que gravan sus propiedades. 10 de agosto de 1935.

- Id. Vecinos de Corzanes, Fiolledo y Pesqueiras piden la supresión de la renta foral de la «Anduriñeira». 15 de agosto de 1935. (Aportan documentos de 1794).

- Id. Vecinos de la parroquia de Pesqueiras piden la supresión de la «Renta Foral de Chano de Arriba y otras que gravan sus tierras. 20 de enero de 1936. (Se presentan documentos del siglo XIX).

"CUADERNOS DE ESTUDIOS GALLEGOS", Tomo XLII, Fascículo 107, Santiago 1995 
- Sangenjo. El Ayuntamiento informa de los despojos sufridos por los bienes comunales del monte Ventureira o Castineiro. 23 de junio de 1931.

- Tomiño. Vecinos de la parroquia de Amorín solicitan la abolición de los foros «Golada» y «da Valiña» que percibe Domingo Fernández y González por haberlos comprado a los herederos del barón de Casa Goda. 29 de agosto de 1934. (Aportan documentos desde 1590, que incluyen en el expediente).

\section{Caja 95}

- Lavadores. La Federación Provincial Agraria solicita la supresión de diversas prestaciones señoriales pagadas a la ex-marquesa de Valladares. 16 de agosto de 1935. (Se aportan documentos fechados en 1647, $1661 \ldots)$.

- Puenteareas. Perfecto Pérez de la parroquia de Nogueiras pide se suprima un foro de origen señorial que pagan al conde de Salvatierra desde tiempos inmemoriales. 18 de febrero de 1935. (Se incluyen escrituras de foros, del siglo XIX).

- Id. El Presidente de la Federación Agraria Provincial pide la supresión de foros de origen señorial pagados por los vecinos de la parroquia de Celeiros. 16 de enero de 1936.

- Redondela. Juan Santos, vecino de la parroquia de Cesantes, pide se declare señorial y se suprima el foro que viene pagando. 27 de mayo de 1935.

- Id. El Presidente de la Federación Provincial Agraria pide la anulación de los foros pagados por vecinos de la parroquia de Cedeiras. $10 \mathrm{de}$ febrero de 1936.

- Id. El Presidente de la Federación solicita la declaración de origen señorial de los foros que pagan vecinos de las parroquias de Negros, Cedira y Quintela. 14 de febrero de 1936.

- Salvatierra de Miño. Vecinos de la parroquia de Oleiros piden la abolición de foros que creen de origen señorial. 5 de agosto de 1935.

- Id. Vecinos de la parroquia de Corzanes piden la supresión de determinados foros que consideran señoriales. 15 de agosto de 1935.

- Id. Vecinos de la parroquia de Oleiros piden la abolición de determinados foros. 16 de diciembre de 1935.

- Tomiño. La parte reclamante (v. la caja anterior) presenta como prueba un libro-catastro de la riqueza de Amorín de 21 de agosto de 1847.

"CUADERNOS DE ESTUdIOS GALLEGOS", Tomo XLII, Fascículo 107, Santiago 1995. 


\section{Foros y Censos}

- Covelo. Vecinos de la parroquia de Barciademera piden la supresión de foros que vienen pagando desde 1640.30 de marzo de 1936 .

- Pontevedra. El Presidente de la Federación Agraria Provincial llama la atención sobre le problema de los foros que afectan a los campesinos gallegos. 20 de julio de 1935.

- Puenteareas. El Presidente de la Federación Provincial Agraria pide la supresión de foros pagados por vecinos de las parroquias de Moreira, Cristiñade y Nogueira. 11 de diciembre de 1935. (Aporta un documento de 1560 , de subforo).

- Id. El Presidente de la Federación Provincial Agraria pide la supresión de los foros que pagan vecinos de las parroquias de Moreira, Nogueira y Cristiñade. 21 de diciembre de 1935.

- Id. id. Se trata de otro expediente abierto a petición de otros pagadores de foros en las mismas parroquias. 21 de diciembre de 1935. (Aporta documentos del siglo XVIII).

- Id. id. 2 de enero de 1936.

- Id. El Presidente de la Federación solicita la supresión de foros pagados por vecinos de las parroquias de San Mateo y Arcos. 9 de enero de 1936.

- Id. El Presidente de la Federación pide la abolición de prestaciones pagadas por vecinos de las parroquias de Moreira y Cristiñade. 9 de enero de 1936.

- Salvatierra de Miño. Vecinos de la parroquia de Corzanes piden la supresión de foros que consideran de origen señorial. 11 de febrero de 1934. (Se aportan numerosos documentos, que se remontan a 1648).

- Id. Vecinos de Corzanes piden la supresión de foros. 11 de febrero de 1934.

- Id. Manuel Domínguez y otros vecinos de Corzanes piden se suprima el foro llamado de la Inquisición. 16 de enero de 1935. (Se incluyen una escritura de foro de 1799 y otros documentos).

- Vigo. El Presidente de la Federación pide se anulen los foros pagados por vecinos de las parroquias de Corujo y Navia. 16 de enero de 1936. (Se incluyen documentos de 1773). 